\title{
The Cell Wall of Prototheca zopfii
}

\author{
By D. LLOYD AND G. TURNER \\ Department of Microbiology, University College, Cathays Park, Cardiff
}

(Accepted for publication I8 August 1967)

\begin{abstract}
SUMMARY
Cell walls of Prototheca zopfii KRUGER $236 / 65$ were prepared by differential centrifugation after disruption of the organisms in a French press. The isolated walls were free from whole organisms and subcellular particles as shown by examination by light and electron microscopy. A quantitative analysis of the walls was made with respect to total nitrogen, phosphorus, ash and lipid. Paper chromatography of hydrolysates of walls showed glucose, mannose, glucosamine and twelve amino acids. A quantitative amino acid analysis was made by ion-exchange chromatography; trace amounts of several other amino acids were detected. The structure of the walls was studied before and after treatment with $\mathrm{NaOH}$ and a variety of hydrolytic enzymes. The results are compared with those obtained by other workers with various species of Chlorella, Aspergillus and yeasts. The results are discussed with reference to the taxonomic position of Prototheca zopfii.
\end{abstract}

\section{INTRODUCTION}

Prototheca zopfii is a unicellular colourless organism which lives heterotrophically and has been classified as an achlorotic relation of the genus Chlorella on the basis of morphology and life cycle (Beijerinck, I904; Chodat, I9I3; Printz, I927). A comparison between the nutrition and metabolism of artificially produced colourless mutants of Chlorella and Prototheca was made by Ciferri; while Prototheca required added thiamine for growth, the green forms and their colourless mutants were able to synthesize thiamine (Ciferri, 1957). The colourless mutants of Chlorella, like Prototheca no longer have the autotrophic mechanism of $\mathrm{CO}_{2}$ fixation and incorporate $\mathrm{CO}_{2}$ by carboxylation of phosphoenolpyruvate (Ciferri \& Sala, I962; Lloyd \& Callely, 1965). Ciferri concluded that such differences as exist between the organisms studied might be explained if some changes had occurred during the evolution of Prototheca from the colourless forms of Chlorella. An alternative explanation which he considered was that Prototheca was not an alga but an ascomycete with ascospores and without vegetative stages of reproduction, as was originally proposed by Saccardo \& Traverso (I9II).

Since cell-wall composition has been used as a taxonomic criterion in recent years it was decided to examine the cell wall of Prototheca in the light of recent investigations on walls from Chlorella (Northcote, Goulding \& Horne, I958; Punnett \& Derrenbacker, 1966), Aspergillus (Johnston, 1965) and yeast (Korn \& Northcote, 1960). It was also hoped that such a study might provide information for the preparation of protoplasts of this organism. A preliminary report of the results obtained has been published (Turner \& Lloyd, 1966). 


\section{METHODS}

The organism used in this work was a culture of Prototheca zopfii KRUGER 263/65 isolated by E. F. Pringsheim, obtained from the Culture Collection of Algae and Protozoa at Cambridge University. The organism was maintained and grown with acetate as sole carbon source as previously described (Callely \& Lloyd, 1964). The cultures were harvested by centrifugation at $1500 \mathrm{~g}$ for $10 \mathrm{~min}$. and washed twice with distilled water. Cell breakage was usually done by two passages through a French press (Milner, Lawrence \& French, 1950) at $2^{\circ}$ under a pressure of $37,000 \mathrm{lb}$./in. ${ }^{2}$; this method gave virtually complete disruption of the organisms. Large pieces of wall for electron microscope examination were prepared after breakage in a French press at 20,000 lb./in. ${ }^{2}$.

Cell wall preparation. The broken cell suspension was diluted with distilled water and centrifuged at $800 \mathrm{~g}$ for Io min. in an MSE ' 17 ' centrifuge $(6 \times 250 \mathrm{ml}$. head). The supernatant fluid, consisting of all particles and soluble fraction, was discarded and the residue (cell walls and contaminating particles) was suspended in $200 \mathrm{ml}$. tris buffer $(2 \mathrm{~g} . / 1 . ; \mathrm{pH} 7 \cdot 0)$ and $\mathrm{o}^{\circ} \mathrm{I} \mathrm{ml}$. Tween 80 added. The suspension was thoroughly dispersed with a hand homogenizer and centrifuged at $800 \mathrm{~g}$. These operations were repeated until the cell walls had been washed, dispersed and centrifuged six times. Finally, the wall material was centrifuged at $1500 \mathrm{~g}$ ro min. and washed twice with distilled water.

Examination of the walls at this stage of purification by light and electron microscopy indicated that the broken and torn fragments were not visibly contaminated by whole organisms or adhering subcellular particules. The possibility that absorbed soluble protein was still present could not be discounted. The wet walls were heated at $55^{\circ}$ until most of the water had been removed, and the drying completed in a vacuum desiccator over silica gel at room temperature; storage was at $-15^{\circ}$ over the desiccant.

Analysis of walls. Ash was determined on a sample of material that had been maintained at red heat for $\mathrm{I} \mathrm{hr}$ in a silica combustion tube. Lipid was estimated gravimetrically after separate extractions with boiling methanol and ether. Total nitrogen was determined by the micro-Kjeldhal method of Chibnall, Rees \& Williams (I943); digestion of the wall material was followed by distillation of the $\mathrm{NH}_{3}$ and titration. Total phosphorus was determined by the method of Fiske \& SubbaRow as modified by Leloir (1957); organic phosphorus was first converted to phosphate by digesting walls with concentrated $\mathrm{H}_{2} \mathrm{SO}_{4}$.

For amino acid analysis 5-10 mg. samples of wall were hydrolysed in $5 \mathrm{ml}$. of $6 \mathrm{~N}-\mathrm{HCl}$ for $48 \mathrm{hr}$ in sealed tubes at $110^{\circ}$. The hydrolysates were evaporated to dryness at $60^{\circ}$ and stored in vacuum over $\mathrm{NaOH}$ at $-15^{\circ}$. Qualitative analysis of the amino acids by two-dimensional paper chromatography was made with the solvent systems of Calvin \& Benson (1949) or of Stepka (1957). A ninhydrin spray (0.3\% in $n$-butanol) was used to detect the amino acids on the chromatograms. Quantitative amino acid analysis was done by ion-exchange chromatography according to Moore \& Stein (I95I) by using a Technicon Amino Acid Autoanalyzer.

Paper chromatography of sugar components was done on $\mathrm{HCl}$ hydrolysates and on $\mathrm{BaCO}_{3}$-neutralized $\mathrm{H}_{2} \mathrm{SO}_{4}$-hydrolysates $\left(2 \mathrm{~N} ; 100^{\circ} ; \mathrm{I} 2 \mathrm{hr}\right.$ ). The solvent system used was that of Jermyn \& Isherwood (I949) and the sprays were $p$-anisidine $\mathrm{HCl}(0 \cdot \mathrm{I} \%$ 
in acetone) or resorcinol. The same solvents and sprays, also the ninhydrin spray, were used to detect amino sugars.

The effects of various enzymes ( $\mathrm{I}-2 \mathrm{mg}$. $/ \mathrm{ml}$.) were tested by incubation with whole organisms in tris buffer $(\mathrm{pH} 6.0)$ for $3 \mathrm{hr}$ at $30^{\circ}$. The sources of enzymes used were as follows: cellulase (from Aspergillus niger), chitinase, hyaluronidase, glucuronidase, mycozyme (from $A$. oryzae), papain, all from Koch-Light, Colnbrook, Bucks; trypsin, papain, pancreatin, all from British Drug Houses, Poole, Dorset; snail digestive enzyme Glusulase was from Endo Laboratories Inc. Richmond Hill, New York, and from Industries Biologique Francaise, 35 à 49 Quai de Moulin de Cage, Gennevilliers (Seine), France. The suspensions of organisms were examined, after enzyme treatment, by the light microscope; the gross integrity of the walls was easily assessed by this method.

Whole organisms for sectioning were fixed in $2 \%(\mathrm{w} / \mathrm{v})$ osmium tetroxide solution

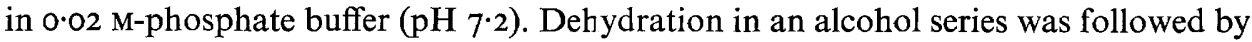
embedding in a $9+\mathrm{I}(\mathrm{v} / \mathrm{v})$ mixture of $n$-butyl methacrylate + methyl methacrylate and the blocks were sectioned at $60 \mathrm{~m} \mu$ on a Huxley Ultramicrotome (Cambridge Instrument Co., Cambridge). The sections were stained on the grids with lead, (Lever, I960).

Fragments of cell wall were fixed as for whole cells, spread on formvar-coated grids, and shadowed at $45^{\circ}$ with platinum. Grids were examined in an Akashi T.S. 50 or an A.E.I. EM. 6 operating at $75 \mathrm{kV}$.

\section{RESULTS}

\section{Yield of and composition of cell-wall material}

From $20 \mathrm{l}$. of culture giving $50 \mathrm{~g}$. wet wt organisms about $400 \mathrm{mg}$. dry light-yellow wall material were obtained. This contained the following constituents: ash $6.5 \%$; lipid I . $6 \%$; total nitrogen $\mathrm{I} \cdot 6 \%$; total phosphorus $0.09 \%$.

Amino acid analysis. The amino acids detected in the wail material by paper chromatography were: leucine, phenylalanine, alanine, glycine, serine, glutamic acid, histidine, arginine, aspartic acid, lysine, cysteine, proline. No diaminopimelic acid was detected. Glucosamine was present. The quantitative amino acid analysis obtained by ion-exchange chromatography is presented in Table $\mathrm{I}$.

Sugar analysis. The only sugar components detected were glucose and mannose in approximately equimolar amounts. The solvents and sprays used clearly distinguish between these sugars and other sugars used as references (galactose, arabinose, xylose, rhamnose).

\section{Treatment of whole organisms with enzymes}

The following enzyme preparations and mixtures were incubated with suspensions of whole organisms: cellulase, chitinase, hyaluronidase, glucuronidase, mycozyme, papain, trypsin, pepsin, pancreatin, culture filtrate of Trichoderma viride (from Dr M. Davies), snail digestive enzymes + 2-aminoethanethiol, snail enzymes + papain. Examination in the light microscope of organisms incubated up to $24 \mathrm{hr}$ revealed that none of the enzymes produced any great changes in the appearance of the walls and in no case was there any significant lysis of the organisms. Wall preparations or whole organisms added to mixed cultures of soil micro-organisms showed no signs of disruption even after several months. The Prototheca organisms were found to pass through the alimentary canal of pond snails without being digested. 


\section{Electron microscopy}

Sections of whole organisms, prepared after $\mathrm{OsO}_{4}$ fixation, showed that the wall was about $1000 \AA$ thick (mean diam. of log phase organisms, $14 \mu$ ) and consisted of a thin $(200 \AA)$ outer osmiophilic layer and a much thicker ( $800 \AA)$ inner electrontranslucent layer (Pl. I, fig. I). The outer surface appeared to be highly corrugated and bore hemispherical projections (nodules) of various sizes. Surface views of the walls in shadowed preparations showed the nodules as electron-dense protrusions; these

Table I. Amino acid, sugar and amino sugar composition of hydrolysates of walls of Prototheca zopfii KRUGER 236/65; comparison with results for Chlorella species (Punnett \& Derrenbacker, 1966), Aspergillus niger (Johnston, 1965) and Saccharomyces cerevisiae (Korn \& Northcote, 1960)

\begin{tabular}{|c|c|c|c|c|}
\hline & $\begin{array}{c}\text { Prototheca } \\
\text { zopfii } \\
\text { (m } \mu \text { moles/mg. } \\
\text { cell wall) }\end{array}$ & $\begin{array}{l}\text { Chlorella } \\
\text { species }\end{array}$ & $\begin{array}{l}\text { Aspergillus } \\
\text { niger }\end{array}$ & $\begin{array}{l}\text { Saccharomyces } \\
\text { cerevisiae }\end{array}$ \\
\hline Aspartic acid & $17 \cdot 2$ & $+t$ & + & + \\
\hline Threonine & $\mathrm{I} 4 \cdot 8$ & - & + & + \\
\hline Serine & $23 \cdot 0$ & ++ & + & + \\
\hline Glutamic acid & $16 \cdot 8$ & ++ & + & + \\
\hline Glycine & 19.9 & ++ & + & + \\
\hline Alanine & $23 \cdot 2$ & ++ & + & + \\
\hline Isoleucine & $8 \cdot 9$ & ++ & + & + \\
\hline Leucine & $13 \cdot 7$ & ++ & + & + \\
\hline Phenylalanine & $6 \cdot 3$ & $+^{*}$ & + & + \\
\hline Lysine & $8 \cdot 5$ & - & + & + \\
\hline Arginine & ++ & - & + & - \\
\hline Cysteine & $2 \cdot 8$ & - & + & + \\
\hline Proline & Trace & $++\dagger$ & + & - \\
\hline Valine & Trace $(I \cdot 64)$ & ++ & + & + \\
\hline Methionine & Trace & $+\ddagger$ & - & + \\
\hline Tyrosine & Trace & + & + & + \\
\hline Histidine & Trace $(I \cdot 75)$ & - & + & + \\
\hline Glucose & + & + & + & + \\
\hline Galactose & 一 & + & + & - \\
\hline Mannose & + & + & + & + \\
\hline Glucosamine & $13 \cdot 4$ & + & + & + \\
\hline Galactosamine & - & $+\S$ & + & + \\
\hline
\end{tabular}

In the results for Chlorella, ++ indicates major component, + minor component. ${ }^{*}$ minor component in C. pyrenoidosa, only. $\dagger$ major component in C. pyrenoidosa, hydroxyproline in C. vulgaris. $\$$ minor component in C. vulgaris and C. ellipsoidea. $\S$ detected in C. vulgaris and C. ellipsoidea only.

structures provided an indication of the orientation of the wall, since the nodules were shadowed when presented uppermost but appeared as diffuse dark areas when viewed through the wall (Pl. I, fig. 2, 3, 4). The outer surface of the walls also bore parallel striations while the inner surfaces had a smoother fine-grained structure (Pl. I, fig. $2,3,4)$.

Mild treatment with $\mathrm{NaOH}$ ( $\mathrm{N}$ for $30 \mathrm{~min}$.) had little visible effect on wall structure. Treatment with $5 \mathrm{~N}-\mathrm{NaOH}$ for $13 \mathrm{hr}$ resulted in a disintegration of the walls into irregularly shaped pieces, and saponified lipid products dried on the grids to patches of solid of characteristic vesicular appearance (P1. 2, fig. 5). No microfibrils were seen 
after $\mathrm{NaOH}$ treatment but certain surface corrugations became very much more apparent (P1. 2, fig. 6). Examination of walls after treatment with papain or hyaluronidase revealed little visible change of structure, but the striated appearance of the outer surfaces of the wall seemed to become less obvious after incubation with papain.

\section{DISCUSSION}

The cell wall of Prototheca zopfii is a rigid structure of high tensile strength and the forces required to produce efficient breakage of organisms are very considerable. Previous work has shown that many of the usual methods for the mechanical disruption of micro-organisms are only of limited success when applied to this organism. For example, ultrasonic treatment for periods up to $\mathrm{I} \mathrm{hr}$ at the full output of the MSE $500 \mathrm{~W}$ sonicator, disruption in a Hughes (I95I) press, and methods involving shaking or grinding with glass beads, all produce only a small proportion of broken organisms (Lloyd, 1967).

Marked differences can be seen between the amino acid composition of the wall of Prototheca and that reported for Chlorella species by Punnett \& Derrenbacker (1966). These Chlorella walls were prepared after washing with $\mathrm{M}-\mathrm{NaCl}$ and detergent and the authors claimed that the simplicity of the amino acid patterns detected in six different algae suggested that the wall preparations contained peptides rather than proteins. The quantitative data for Prototheca might suggest that this is indeed the case, as there are twelve major and five minor components, the major amino acid constituents being ten times the concentration of the minor components.

Diaminopimelic acid (DAPA) was not detected in the wall of Prototheca, although Ciferri et al. (196I) showed that extracts of this organism possessed the DAPA activating enzyme. It seems likely that this acid is an intermediate in lysine biosynthesis rather than a wall constituent (Vogel, 1959). With Chlorella species, there have been two reports of the existence of DAPA (Fujiwara \& Akabori, I954; Hoare \& Work, I957), but it is not present as a wall component (Punnett \& Derrenbacker, 1966).

The marked resistance of the wall of Prototheca to attack by a variety of hydrolytic enzymes is another indication of differences between this organism and Chlorella, since the digestive juice of Helix pomatia partially digests walls of Chlorella pyrenoidosa (Northcote et al. 1958).

Sections of the walls of Prototheca showed the presence of only two layers, whereas Chlorella pyrenoidosa walls have an electron translucent layer sandwiched between osmiophilic inner and outer lamellae (Northcote et al. 1958). The presence of nodules on the surface of the walls also distinguishes Prototheca from Chlorella. The origin and nature of these structures is unknown.

Microfibrils such as those observed in Candida tropicalis (Houwink \& Kreger, 1953), bakers' yeast (Nickerson, 1959) and Chlorella pyrenoidosa (Northcote et al. 1958) were not detected in Prototheca, even after treatment with $\mathrm{NaOH}$.

It thus seems that, although Prototheca has long been considered to be a colourless alga closely related to Chlorella, differences in cell wall composition and ultrastructure cast doubt on this relationship.

The authors are indebted to Professor D. E. Hughes for his encouragement, to $\mathrm{Dr} \mathrm{D}$. Johnson for performing the amino acid analysis, and to $\mathrm{Mr} \mathrm{W}$. Henderson for skilled technical assistance with the electron microscopy. D. L. holds an I.C.I. Research Fellowship. 


\section{REFERENCES}

BeIJERINCK, M. W. (I904). Chlorella variegata, ein bunter Mikrobe. Rec. Trav. Bot. Neere I, I4.

Callely, A. G. \& Lloyd, D. (1964). The metabolism of acetate in the colourless alga, Prototheca zopfii. Biochem. J. 90, 483 .

Calvin, M. \& Benson, A. A. (I949). Path of carbon in photosynthesis IV. The identity and sequence of intermediates in sucrose synthesis. Science ro9, 140.

Chibnall, A. C., Rees, M. W. \& Williams, E. F. (1943). Amino acid analysis and the structure of proteins. Biochem. J. 37, 354 .

Chodat, R. (1913). Monographies d'algues en culture pur. In Mat. of FI. Crypt Suisse 4, II, I2I.

Crferri, O. (1957). Metabolismo comparitivo delle Protothecae e delle mutanti achloriche di Chlorellae. G. Microbiol 9, 97.

Ciferri, O. \& Sala, F. (I962). Carbohydrate metabolism of Prototheca zopfii II. Carbon dioxide fixation by cell-free extracts. Enzymologia 84, 298.

Ciferri, O., Girolarno, M. di \& Bendicenti, A. (I96I). Amino acid activation in algae: activation of $\alpha, \epsilon$-diaminopimelic acid. Biochim. biophys. Acta 50, 405.

FuJIWARA, T. \& AKABORI, S. (1954). $\alpha, \alpha^{\prime}$-Diaminopimelic acid in Chlorella ellipsoidea. Jap. J. Chem. 75, 990 .

HOARE, D. \& WORK, E. (1957). The stereoisomers of $\alpha$, -diaminopimelic acid. Biochem. J. 65, 44I.

Houwink, A. L. \& KREGER, D. R. (1953). Cell wall of yeasts-electron microscope and X-ray diffraction. Antonie van Leeuwenhoek I9, I.

Hughes, D. E. (I95I). A press for disrupting bacteria and other micro-organisms. Br. J. exp. Path. 32, 97.

JeRMYN, M. A. \& ISHERWOOD, F. A. (I949). Improved separation of sugars on the paper partition chromatogram. Biochem. J. 44, 402.

Johnston, I. R. (1965). The composition of the cell wall of Aspergillus niger. Biochem. J. 96, 65I.

Korn, E. C. \& NorthCoTe, D. H. (1960). Physical and chemical properties of polysaccharides and glycoproteins of the yeast cell walls. Biochem. J. 75, I 2.

Leloir, L. F. \& CARDINI, C. E. (1957). Characterization of phosphorous compounds by acid liability. Meth. Enzymol. 3, 840 .

LEVER, J. D. (1960). A method of staining sectioned tissues with lead for electron microscopy. Nature, Lond. $\mathbf{1 8 6 , 8 1 0 .}$

LloYd, D. (1967). The isolation of mitochondria from the colourless alga Prototheca zopfii. J. exp. Cell Res. 45, 120.

Lloyd, D. \& Callely, A. G. (1965). The assimilation of acetate and propionate by Prototheca zopfii. Biochem. J. 97, 176.

Muner, H. W., LAWRENCE, N. S. \& French, C. S. (I950). Colloidal dispersion of chloroplast material. Science N.Y. III, 633 .

MOORE, S. \& STEIN, W. H. (I95I). Chromatography of amino acids on sulphonated polystyrene resins. J. biol. Chem. 192, 663 .

Myers, F. L. \& NorthCoTE, D. H. (1958). Cytase activity of the digestive enzymes of Helix pomatia and the purification of a cellulase component. J. exp. Biol. 35, 396.

Nickerson, W. J. (1959). Biochemistry of Morphogenesis, a report on Symposium VI. 4th Int. Congr. Biochem. 14, 191 .

Northcote, D. H., Goulding, K. G. \& Horne, R. W. (1958). The chemical composition and structure of the cell wall of Chlorella pyrenoidosa. Biochem.J. Io, 39I.

Printz, A. (1927). Chlorophyceae in Engler's Die Natürlichen Pflanzen-Familien, 2nd ed. vol. 7, p 463. Berlin: L. W. Engelmann.

PunnetT, T. \& Derrenbacker, E. C. (I966). The amino acid composition of algal cell walls. J. gen. Microbiol. 44, 105.

Saccardo, P. A. \& Traverso, G. B. (I9I I). Prototheca zopfii (Saccharomycetaceae) Syll. Fung. $20,525$.

STEPKA, W (1957). Identification of amino acids by paper chromatography. Meth. Enzymol. 3, 504.

Turner, G. \& Lloyd, D. (1966). The chemical composition and structure of the cell wall of Prototheca zopfii. Biochem. J. 99, 55 P.

VoGEL, H. J. (1959). Lysine biosynthesis in Chlorella and Euglena: phylogenetic significance. Biochim. biophys. Acta 34, 282. 
Journal of General Microbiology, Vol. 50, No. 3

Plate I
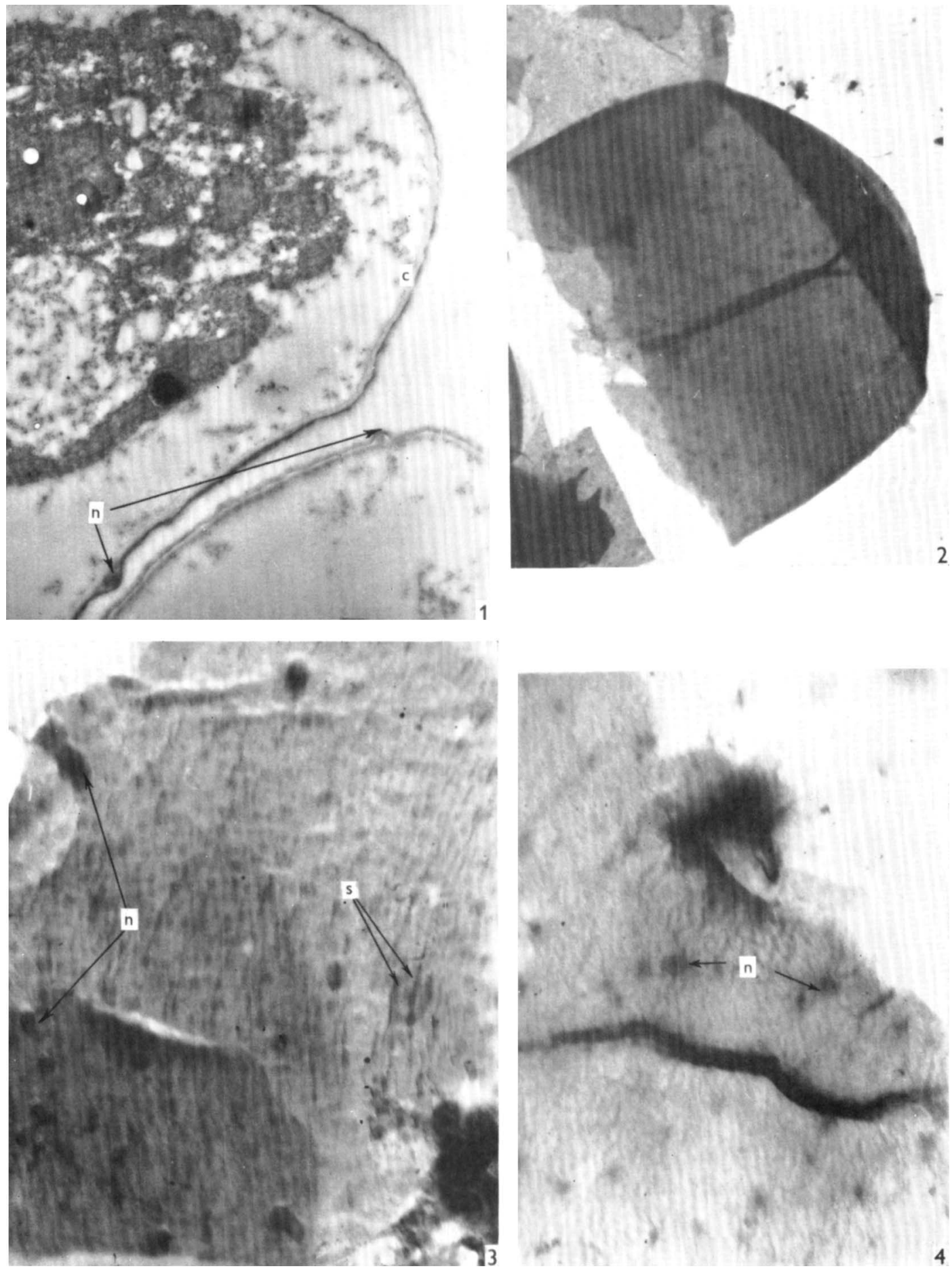

D. LLOYD AND G. TURNER

(Facing p. 426) 
Journal of General Microbiology, Vol. 50, No. 3

Plate 2
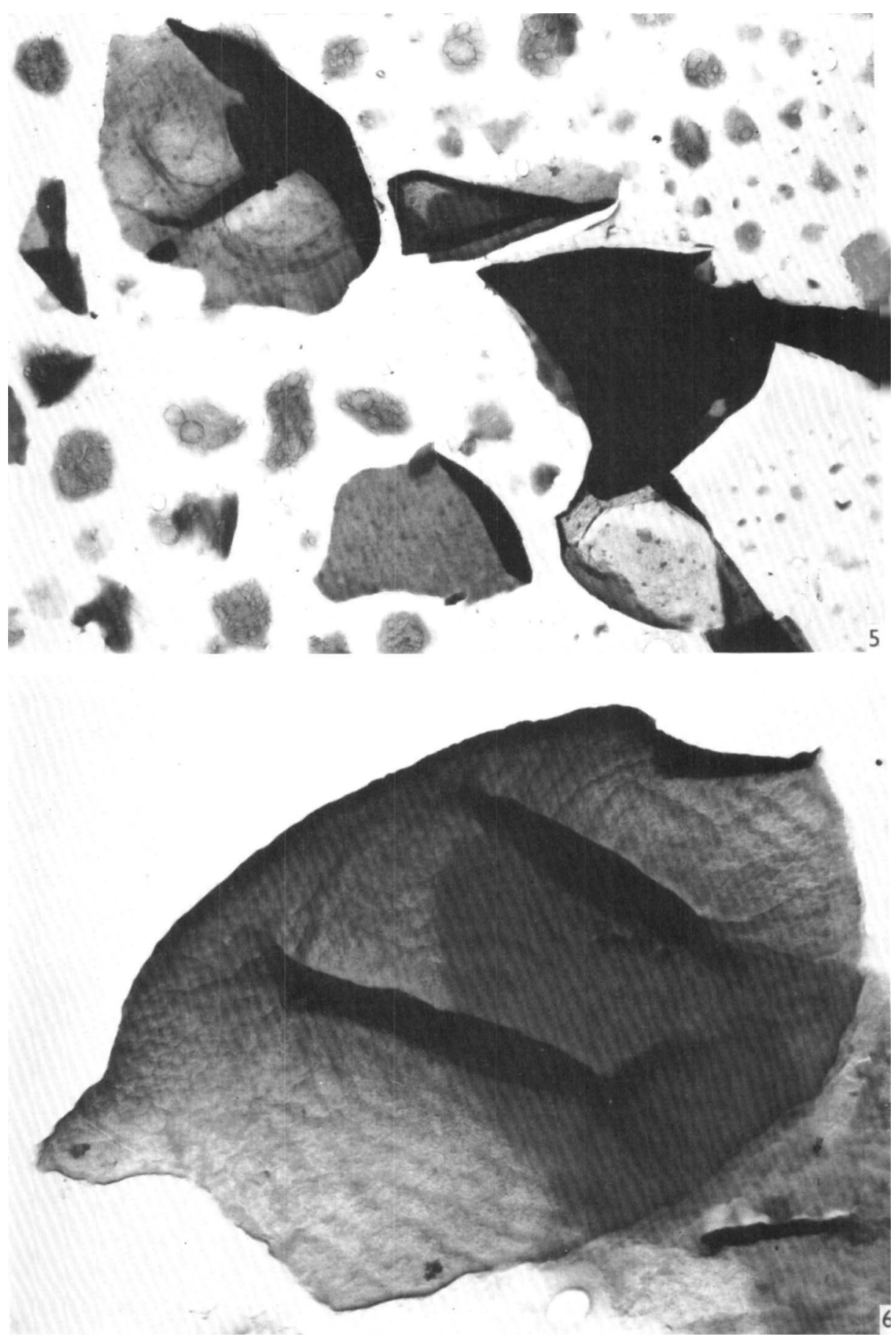

D. LLOYD AND G. TURNER 


\section{EXPLANATION OF PLATES}

\section{P'LATE I}

Fig. I. Prototheca zopfii: section showing cell wall (c) and nodules. (n) $\times 35,000$.

Fig. 2. Cell wall after isolation. $\times 4600$.

Fig. 3. Striations (s) and nodules (n) on outer surface of cell wall. Shadowed. $\times 20,000$.

Fig. 4. Inner surface of cell wall with the nodules (electron dense areas) seen through the cell wall. Shadowed. $\times 20,000$.

\section{Plate 2}

Fig. 5. Cell walls after treatment with $5 \mathrm{~N}-\mathrm{NaOH}$ for $\mathrm{I} 2 \mathrm{hr}$. showing disintegration and saponification of the cell wall lipid. Shadowed. $\times 2,500$.

Fig. 6. Surface corrugations after $\mathrm{NaOH}$ treatment. Shadowed, $\times 15,000$. In the shadowed preparations pictures are positives made from actual negatives obtained (i.e. shadows are white). 